\title{
Buğdayda Başak Yanıklığına Karşı Farklı Çiçeklenme Dönemlerinde Uygulanan Tebuconazole'un Etkinliği
}

\author{
Gülsüm Palacıoğlu ${ }^{1,2}$ iD $\quad$ Figen Mert $^{1 *}$ iD \\ ${ }^{1}$ Çanakkale Onsekiz Mart Üniversitesi, Ziraat Fakültesi, Bitki Koruma Bölümü, Çanakkale \\ ${ }^{2}$ Şırnak Üniversitesi, Ziraat Fakültesi, Bitki Koruma Bölümü, Şırnak \\ "Sorumlu yazar: fmert@comu.edu.tr
}

Geliş Tarihi: 26.05.2021

Kabul Tarihi: 17.06.2021

\section{$\ddot{O} z$}

Fusarium culmorum buğdayda kök ve kök boğazı çürüklüğüne, fide ve başak yanıklığına neden olan tahripkâr bir patojendir. Patojenle mücadelede dünyada konukçu dayanıklılığı, kültürel önlemler ve fungisit uygulamaları yaygın olarak kullanılmaktadır. Ancak fungisit uygulamalarının hastalık gelişiminin önlenmesindeki etkinliği, bitkinin gelişme dönemlerine göre farklılıklar göstermektedir. Bu çalışma kapsamında, buğdayda Fusarium culmorum'un neden olduğu başak yanıklığına karşı inokulasyon öncesi, esnası ve sonrası olmak üzere 7 farklı çiçeklenme döneminde uygulanan tebucanozole’un hastalık gelişimi ve nispi başak ağırlığı üzerindeki etkisi değerlendirilmiştir. Yapılan çalışma sonucunda yeşil aksam ilaçlamasında kullanılan tebucanozole'un tüm uygulamalarının kontrole kıyasla hastalık şiddetini önemli oranda azalttığ belirlenmiştir. $\mathrm{F}_{50}$ (ZGS65) dönemindeki uygulama \%82.3 ile en yüksek etkiyi göstermiş ve hastalığa karşı en etkili uygulama zamanı olduğu tespit edilmiştir. Diğer çiçeklenme dönemlerinde yapılan uygulamalar arasında da istatiksel olarak önemli farklılıkların bulunduğu ve hastalık gelişimini \%36.7-71.7 oranında engellendiği görülmüştür. Ayrıca hastalık gelişimi ile nispi başak ağırlıkları arasında ters orantı olup, enfeksiyonun en düşük olduğu $F_{50}$ döneminde nispi başak ağırlığının en fazla olduğu belirlenmiştir. Bu kapsamda hastalıkla mücadelede \%50 çiçeklenme döneminde yapılacak uygulamalara öncelik verilmesinin faydalı olacağı düşünülmektedir.

Anahtar Kelimeler: Fusarium culmorum, Başak ağırlığı, Başak yanıklığı, Çiçeklenme dönemi, Tebuconazole

\section{Effectiveness of Tebuconazole Applied in Different Anthesis Stages Against Head Blight in Wheat \\ Abstract}

Fusarium culmorum is a devastating pathogen of wheat, causing seedling blight, foot rot, head blight. Host resistance, cultural practices and fungicide applications have been used widely to control this pathogen worldwide. The effect of fungicide applications on disease development differs according to the different stages of plant growing. In this study, effect of tebuconazole against head blight caused by F. culmorum on 7 anthesis stages, such as at the time of inoculation, before inoculation and after inoculation on disease development and seed set, was aimed to determine. The experiments exhibited that all tebuconazole applications significantly reduced disease development compared to diseased control. The application in the mid-anthesis stage (F50; ZGS65) showed the highest effect with $82.3 \%$ and it was found to be the most effective application time against the disease. There were statistically significant differences between the applications in other anthesis stages and the disease development was prevented by $36.7-71.7 \%$. Also, relative head weight was the highest in this time. The result showed that tebucanozole applications in $\% 50$ anthesis stage will be beneficial to manage the disease. Keywords: Anthesis stage, Disease development, Fusarium culmorum, Head blight, Tebuconazole

\section{Giriş}

Buğday geniş adaptasyon yeteneğine sahip olması nedeniyle ülkemizde ve dünyada en fazla yetiştirilen tahıllardan bir tanesidir. Ancak birçok tarım ürününde olduğu gibi buğday üretiminde de çok sayıda hastalık etmeni bulunmakta ve önemli ürün kayıplarına neden olmaktadır. Buğdayda görülen fungal hastalık etmenleri içerisinde Fusarium türleri önemli bir yer tutmakta olup bitkinin kök ve kök boğazında, başak ve tanesinde enfeksiyonlara neden olmaktadır. Başak hastalıkları arasında ise Fusarium başak yanıklığı (Fusarium Head Blight, FHB) yaygın olarak görülmekte ve üründe ciddi ekonomik kayıplara neden olmaktadır (McMullen ve ark., 2012). Farklı Fusarium türleri FHB'ye neden olmakla birlikte Fusarium culmorum (Wm.G. Sm.) Sacc. ve F. graminearum Schwabe en önemli etmenler olarak karşımıza çıkmaktadır (Parry ve ark., 1995; Matny, 2015). Hastalık 
simptomları, enfekteli bitkilerin başakları üzerinde bir veya birkaç başakçık kavuzunda küçük beyaz lekeler şeklinde başlamakta ve sonrasında başakçıktan aşağı ve yukarı doğru ilerleyerek başağın tamamında renk açılmasına neden olmaktadır. Ayrıca başaklar üzerinde etmenin pembe renkli miselyumları oluşmakta ve daneler zayıf, buruşuk, beyaz veya pembe renkli görünüm almakta ve dane ağırlı̆̆ının düşmesine neden olmaktadır (Stenglein ve Rogers, 2010).

Buğdayda başak yanıklığı ile savaşımda ekim nöbeti, dayanıklı çeşitlerin seçimi ve kültürel önlemler önerilmekle birlikte patojenin gelişimi için iklim koşulları uygun olduğunda kimyasal mücadele kaçınılmaz olmaktadır. Bu kapsamda, FHB yönetiminde sistemik etkili fungisitlerin hastalık şiddetini azaltmada etkili bir yöntem olduğu görülmüştür (Ellner, 1997; Verreet ve Klink, 2001). Dünyada farklı araştırıcılar tarafından yapılan çalışmalarda, triazole grubunda yer alan tebuconazole, propinocazole, metconazole etken maddelerinin FHB enfeksiyonuna karşı oldukça olumlu sonuçlar verdiği bildirilmiştir (Mauler-Machnic ve Zahn, 1994; McMullen ve ark., 1997; Haidukowski ve ark., 2012; Caldwell ve ark., 2017). Etki mekanizması sistemik olan bu fungisitler uygulandıkları dokuların içerisine nüfuz ederek ksilem ile bitkinin diğer dokularına taşınmaktadır. Bitki dokusuna ulaşan fungal etmenler enfeksiyon oluştursun veya oluşturmasın fungisitlerle temas ettiğinde, fungal yapılarının bozulması sonucu hastalık oluşumu ve gelişimi engellenmektedir (Solel, 1970). Bununla birlikte bu ilaçların etkinliğinin uygulama zamanı, uygulama şekli, konukçu bitki dayanıklılığı, bitki vejetasyonu ve çevre koşullarına göre değişkenlik gösterdiğgi bilinmektedir (Mauler-Machnic ve Zahn 1994; Homdork ve ark., 2000; Matthies ve Buchenauer, 2000; Caldwell ve ark., 2017). Yapilan önceki çalışmalarda kullanılan ilaçların bu patojenlere karşı aktivitesinde farklılıklar olduğu bildirilmiştir (Cromey ve ark., 2001; Pirgozliev ve ark., 2008). Yine FHB'ye karş1 yapılan fungisit uygulamalarının üründe dane özelliklerini etkileyerek verimi arttırdığ gözlenmiştir (Jones, 2000; Matthies ve Buchenauer, 2000). Ülkemizde buğdayda başak yanıklı̆g 1 enfeksiyonuna karşı kimyasal mücadelede prothioconazole+tebuconazole aktif maddeli fungisitler ile ilaçlama önerilmektedir (BKÜ, 2021). Bu kapsamda yapılan çalışmalarda, Akgül ve Erkılıç (2016) tohum ve fide döneminde uygulanan farklı fungisitler arasında tebucanozole'un hastalık şiddetini engellemede en etkili aktif madde olduğunu belirtmiştir. Köycü ve ark. (2018) F. culmorum'un neden olduğu kök ve kök boğazı çürüklügüne karş1 tebucanozole+metalaxyl-M karışımının fide çıkış oranını arttırdığı ve hastalık şiddetini azalttığını bildirmiştir. Toçan ve Mert (2019) ise in vitro koşullarda tebuconazole etken maddeli kimyasalların $F$. culmorum'un miselyal gelişimini yavaşlattığı, çimlenen konidilerde çim tüplerinde deformasyona neden olduğu bildirmiştir. Bu çalışma kapsamında da buğdayda farklı çiçeklenme zamanlarında uygulanan tebucozanole'un Fusarium culmorum'un neden olduğu enfeksiyonun gelişimine ve tane verimine etkisinin belirlenmesi amaçlanmıştır.

\section{Materyal ve Yöntem}

Çalışmada Fusarium başak yanıklığına karşı hassas olduğu bilinen Gönen buğday çeşidi, patojen olduğu daha önceki çalışmalarda tespit edilen ve Çanakkale 18 Mart Üniversitesi Ziraat Fakültesi Bitki Koruma Bölümü kültür koleksiyonunda saklanan Fusarium culmorum izolatı ile tebuconazole etken maddeli (Folicur WP 25, Bayer) fungisit kullanılmıştır.

\section{Denemenin kurulması ve fungisit uygulamaları}

Deneme, Çanakkale Onsekiz Mart Üniversitesi Dardanos Araştırma ve Uygulama arazisinde, tesadüf blokları deneme desenine göre üç tekerrürlü olarak kurulmuştur. Buğday ekimi; parsel genişliği $1 \mathrm{~m}$, parsel uzunluğu $2.5 \mathrm{~m}$, sıra arası $12.5 \mathrm{~cm}$ olarak belirlenen parsel alanlarında ekim mibzeri ile gerçekleştirilmiştir. Tebucanozole uygulamaları önerilen dozda (75 gr/da) inokulasyon öncesinde, esnasında ve sonrasında bitkilerin toprak üstü aksamına homojen bir şekilde püskürtülerek uygulanmıştır. Uygulamalar aşağıda belirtildiği şekilde planlanmıştır:

(a) Kontrol (-) parselleri: F. culmorum ile inokule edilmemiş parseller,

(b) Kontrol (+) parselleri: F. culmorum ile inokule edilmiş fakat ilaçlanmamış parseller,

(c) F. culmorum ile inokule edilmiş ve farklı dönemlerde ilaçlama uygulanmış parseller

Bu kapsamda tebucanozole uygulamaları zadoks büyüme skalasına göre bitkinin 7 farklı çiçeklenme döneminde yapılmıştır:

1. uygulama $\left(\mathrm{F}_{-7}\right)$ : İnokulasyondan 7 gün önce (Zadoks Growth Stage (ZGS) 55-60)

2. uygulama $\left(\mathrm{F}_{0}\right)$ : Başakların çıktı̆̆ fakat henüz çiçeklenmenin başlamadığı dönem (ZGS 60)

3. uygulama $\left(\mathrm{F}_{25}\right)$ : Başakta çiçeklerin \%25'inin açtığı dönem (ZGS 60-65) 
4. uygulama $\left(\mathrm{F}_{50}\right)$ : Başakta çiçeklerin \%50'inin açtığ dönem (ZGS 65)

5. uygulama $\left(\mathrm{F}_{75}\right)$ : Başakta çiçeklerin \%75'inin açtı̆̆ dönem (ZGS 65-69)

6.uygulama $\left(\mathrm{F}_{100}\right)$ : Başakta çiçeklerin \%100'inin açtığı dönem (ZGS 69)

7.uygulama $\left(\mathrm{F}_{+7}\right)$ : İnokulasyondan 7 gün sonra (ZGS 69-75)

\section{Patojen inokulumunun hazırlanması, inokulasyon zamanı ve yöntemi}

Fusarium culmorum izolatı PDA ortamında $24 \pm 1^{\circ} \mathrm{C}$ 'de 14 gün süreyle geliştirilmiştir. İnokulasyondan hemen önce kültürün üzerine yaklaşık $10 \mathrm{ml}$ steril saf su eklenmiş ve bir spatula yardımıyla sporlar hafifçe kazınarak suya geçmesi sağlanmıştır. Elde edilen spor süspansiyonu 2 kat ince tülbentten geçirilmiş, konidi konsantrasyonu thoma lamı ile sayılarak $5 \times 10^{5} \mathrm{konidi} / \mathrm{ml}$ 'ye ayarlanmıştır. Hazırlanan spor süspansiyonunun homojenliğini sağlamak için Tween20 eklenmiş ve inokulum 2-3 saat içerisinde kullanılmıştır (Miedaner ve ark., 2003). İnokulasyon amaciyla her parselden rastgele 30 başak seçilmiş ve her parsel ayrı renkli iplerle işaretlenmiştir. İşaretlenen başakların tam ortasındaki 2 başakçığa yaklaşık 10'ar $\mu 1$ inokulum şırınga yöntemi ile uygulanmıştır. İnokulasyon, buğdayın $F$. culmorum'a en hassas olduğu yaklaşı \%50 çiçeklenme döneminde (ZGS 65) yapılmıştır. Patojen gelişimini teşvik etmek amacıyla inokulasyonun yapıldığ 1 başaklara 48 saat süreyle polietilen torba geçirilerek nemin korunması sağlanmıştır.

\section{Hastalık gelişiminin değerlendirilmesi ve nispi başak ağırlıklarının saptanması}

Hastalık gelişimimlerinin izlenmesi, işaretlenen başaklardaki hastalık belirtisi gösteren alanların tüm başağın boyuna oranla \% olarak değerlendirilmesi ile hesaplanmıştır (Miedaner ve ark., 2003). Gözlemler inokulasyonu takiben 7, 14 ve 21. günlerde gerçekleştirilmiştir. Ayrıca tebuconazole'un 21. günde hastalık gelişiminin engellenmesine olan etkisi Abbott formülü ile değerlendirilmiştir (Karman, 1971).

Başaklar yeterli olgunluğa ulaştığında başak sapının $10 \mathrm{~cm}$ altından kesilerek uygulamalara göre isimlendirilen kese kâğıtlarına konulmuş ve rutubetsiz ortamda 15 gün süreyle kurutulmuştur. Kurutulan başaklar hassas terazide tartılmış ve gruplar içerisinde ortalama alınarak nispi başak ağırlıkları tespit edilmiştir. Elde edilen veriler SAS V8 istatistik paket programı PROC GLM komutu kullanılarak varyans analizi yapılmıs ve ortalamalar arasındaki fark Fisher LSD metodu kullanılarak $(p=0.05)$ değerlendirilmiştir.

\section{Bulgular ve Tartışma}

Fusarium culmorum buğday ekim alanlarında başak yanıklığı, kök ve kök boğazı çürüklügüne sebep olan önemli bir patojen olup üründe ciddi ekonomik kayıplar oluşturmaktadır. $\mathrm{Bu}$ nedenle dünyada patojene karşı mücadelede farklı fungisit uygulamalarının etkinliğini araştıran çok sayıda çalışma yapılmıştır (Milus ve Parsons, 1994; Matthies ve Buchenauer, 2000; Greenfield ve Rossall, 2000; Dardis ve Walsh, 2000; Jones, 2000; Wiersma ve Motteberg, 2005; Hauser-Hahn ve ark., 2008; Pirgozliev ve ark., 2008; Haidukowski ve ark., 2012). Bu çalışmada da buğdayın farklı çiçeklenme dönemlerinde tebucanozole uygulamasının başak yanıklığının gelişimi ve tane verimi üzerindeki etkisi araştırılmıştır. İnokulasyondan birkaç gün sonra hastalık simptomları ilk olarak kontrol (+) grubundaki başakçıklarda inokulasyon noktasında küçük sarı lekeler şeklinde görülmüştür (Şekil 1). Lekeler zamanla başakçık ekseninde yukarı ve aşağ 1 doğru ilerleyerek diğer başakçıklara yayılmış ve en sonunda tüm başağı kaplamıştır. Enfeksiyon ilerledikçe hastalığın gelişimi başaklarla sınırlı kalmamış başak sapında da gözlenmiştir. Ancak tebuconazole uygulanan parsellerdeki başaklarda hastalık simptomları kontrol (+)'e kıyasla daha yavaş ortaya çıkmıştır.

İnokulasyondan 7, 14 ve 21 gün sonra değerlendirilen enfeksiyon alanı incelendiğinde kontrol ve uygulama zamanları arasında önemli farklılıklar olduğu görülmüştür (Çizelge 1). İnokulasyondan 7 gün sonra hastalık gelişimi kontrol $(+)$ parsellerindeki başaklarda \%20.4 olarak tespit edilirken, farklı çiçeklenme dönemlerinde tebucanozole uygulanan parsellerdeki başaklarda \%1.3-11.9 arasında değişmiştir. Bunun yanında $\mathrm{F}_{100}$ ve $\mathrm{F}_{+7}$ uygulama zamanlarında diğer çiçeklenme dönemlerine göre hastalık gelişiminin daha fazla olduğu belirlenmiştir. İnokulasyondan 14 gün sonra yapılan değerlendirmede ise kontrol $(+)$ grubunda enfeksiyon gelişimi \%49.1 olarak tespit edilmiş bunu $\% 32.3$ değeri ile $F_{+7}$ uygulamas1 izlemiştir. Bununla birlikte 14. günde $F_{25}, F_{50}$ ve $F_{75}$ dönemlerindeki uygulamalarda hastalık gelişiminin \%3.8-6.2 arasında olduğu ve enfeksiyonun yavaş ilerlediği tespit edilmiştir. 21. gün yapılan değerlendirmelerde ise en düşük hastalık gelişiminin \%14.3 
ile $\mathrm{F}_{50}$ döneminde gözlendiği ve diğer tüm uygulama zamanlarından farklı olduğu tespit edilmiştir. $\mathrm{F}_{-7}$, $F_{0}, F_{25}$ ve $F_{75}$ dönemlerindeki uygulamaların ise patojen gelişimini engellemede benzer sonuçlar verdiği ve $\mathrm{F}_{50}$ 'den sonra en etkili uygulama zamanı oldukları belirlenmiştir. $\mathrm{F}_{100}$ ve $\mathrm{F}_{+7}$ dönemlerinde ise kontrolden daha düşük hastalık gelişimi görülmekle birlikte diğer uygulama zamanları kadar önleyici olmadığı görülmüştür.
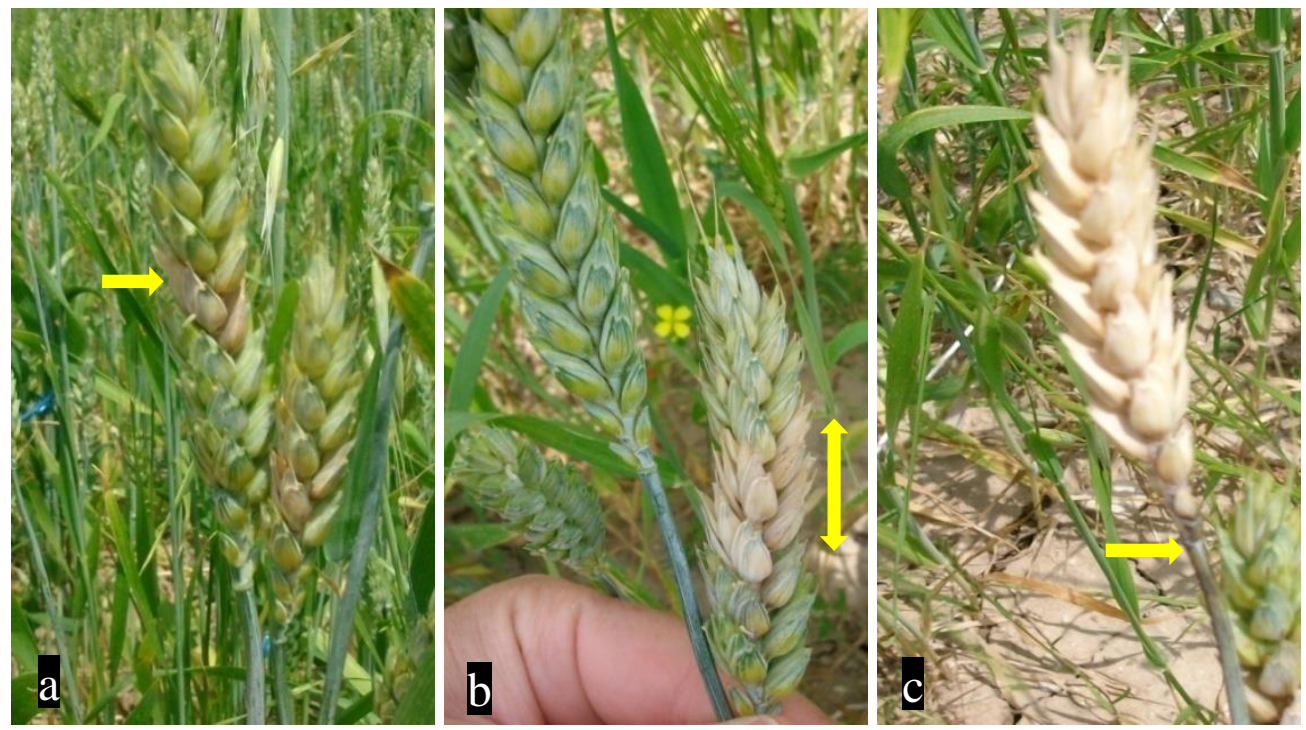

Şekil 1. Fusarium culmorum ile inokule edilen başaklarda görülen hastalık simptomları (ok). (a) İnokulasyonun yapıldığı başakçıktaki sararmalar (ok); (b) Hastalığın diğer başakçıklara doğru ilerlemesi (ok); (c) Hastalığın başak sapına ilerlemesi (ok)

Çizelge 1. Buğdayın farklı çiçeklenme dönemlerinde tebuconazole uygulanan başaklardan elde edilen hastalık gelişimi yüzdeleri (\%) ve hastalık çıkışının engellenme (\%) değerleri

\begin{tabular}{lcccc}
\hline Uygulama dönemi & 7.gün (\%) & 14.gün (\%) & 21.gün (\%) & $\begin{array}{c}\text { 21.gün Hastalığın } \\
\text { Engellenmesi (\%) }\end{array}$ \\
\hline $\mathrm{F}_{-7}$ (ZGS 55-60) & $1.8 \mathrm{~d}^{*}$ & $8.5 \mathrm{~cd}$ & $26.6 \mathrm{~d}$ & 67.0 \\
$\mathrm{~F}_{0}$ (ZGS 60) & $1.6 \mathrm{~d}$ & $8.1 \mathrm{~cd}$ & $23.0 \mathrm{~d}$ & 71.5 \\
$\mathrm{~F}_{25}$ (ZGS 60-65) & $1.4 \mathrm{~d}$ & $6.2 \mathrm{~d}$ & $24.8 \mathrm{~d}$ & 69.3 \\
$\mathrm{~F}_{50}$ (ZGS 65) & $1.3 \mathrm{~d}$ & $6.3 \mathrm{~d}$ & $14.3 \mathrm{e}$ & 82.3 \\
$\mathrm{~F}_{75}$ (ZGS 65-69) & $2.1 \mathrm{~d}$ & $3.8 \mathrm{~d}$ & $22.8 \mathrm{~d}$ & 71.7 \\
$\mathrm{~F}_{100}$ (ZGS 69) & $5.7 \mathrm{c}$ & $11.3 \mathrm{c}$ & $32.5 \mathrm{c}$ & 59.7 \\
$\mathrm{~F}_{+7}$ (ZGS 69-75) & $11.9 \mathrm{~b}$ & $32.3 \mathrm{~b}$ & $51.1 \mathrm{~b}$ & 36.7 \\
Kontrol $(+)$ & $20.4 \mathrm{a}$ & $49.1 \mathrm{a}$ & $80.8 \mathrm{a}$ & 0 \\
\hline
\end{tabular}

*Aynı sütunda farklı harflerin gösterimi istatistiki açıdan fark olduğunu göstermektedir $(p=0.05)$

Patojen inokulasyonundan 21 gün sonra enfekteli bitkilerdeki hastalık engelleme değerleri incelendiğinde ise en yüksek etkinin $\mathrm{F}_{50}$ (ZGS65) döneminde yapılan uygulama ile sağlandığ1 gözlemlenmiştir (Çizelge 1). Bu dönemde yapılan uygulama hastalık gelişimi üzerinde oldukça etkili olup kontrole kıyasla \%82.3'lük bir engelleme sağlamıştır. Diğer dönemlerde yapılan uygulamalar incelendiğinde ise $F_{0}$ ve $F_{75}$ dönemlerinde sırasıyla 71.5 ve 71.7 oranında engelleme sağlanmıştır. Ayrıca genel olarak değerlendirildiğinde inokulasyon sonrası diğer uygulamaların hastalık gelişimi üzerinde düşük seviyelerde etkili olduğu görülmüştür. Benzer şekilde $\% 50$ çiçeklenme döneminde $F$. culmorum ile başak inokulasyonu yapan ve farklı çiçeklenme dönemlerinde tebuconazole ve prochloraz uygulayan Matthies ve Buchenauer (2000), hastalığı önlemede en etkili dönemin ZGS65 olduğunu ve bu dönemde tebuconazole'un hastalık gelişimini \%56, prochloraz'in ise \%41'e kadar azalttı̆̆ını bildirmiştir. Araştırıcılar aynı zamanda ZGS60 ve ZGS69 dönemlerinde yapılan uygulamaların daha düşük etkiye sahip olduğunu belirtmiştir. Wiersma ve Motteberg (2005), ZGS39 ve ZGS60 dönemlerinde tebuconazole uygulamış ve ZGS60 döneminde yapılan uygulamanın enfeksiyon şiddetini azaltmada daha üstün olduğunu bildirmiştir. Homdork ve ark. (2000) ise 
buğdayda $F$. culmorum inokulasyonundan birkaç gün önce ve sonra tebuconazole uygulaması yapmış ve inokulasyon öncesi uygulamaların daha başarılı sonuçlar verdiğini bildirmiştir. Benzer şekilde Pirgozliev ve ark. (2008) çiçeklenmenin yarısında yapılan inokulasyondan 2 gün önce ve 2 gün sonra yapılan uygulamaların en etkili zaman olduğunu belirtmiştir. Araştırıcılar inokulasyon öncesinde ve esnasında yapılan tebucanozole uygulamalarının koruyucu özellik göstererek hastalığın gelişimini yavaşlattığını bildirmiştir (Pirgozliev ve ark., 2008; Wiersma ve Motteberg, 2005).

Tebuconazole'un başak ağırlı̆̆ına etkisini araştırmak amacıyla hastalıklı başak ağırlıkları sağlıklı başak ağılıklarına bölünerek nispi başak ağırlığı belirlenmiştir. Hastalık gelişimiyle orantılı olarak nispi başak ağırlıklarında da uygulamalar arasında önemli farklılıklar olduğu tespit edilmiştir (Şekil 2). Bu kapsamda hastalık gelişiminin en düşük olduğu $F_{50}$ döneminde nispi başak ağırlığının en fazla olduğu görülmüştür. İnokulasyon öncesi $\left(\mathrm{F}_{-7}, \mathrm{~F}_{0}, \mathrm{~F}_{25}\right)$ uygulama yapılan dönemlerdeki nispi başak ağırlıklarının inokulasyon sonrası $\left(\mathrm{F}_{75}, \mathrm{~F}_{100}, \mathrm{~F}_{+7}\right)$ uygulamalardakinden daha fazla olduğu belirlenmiştir. Homdork ve ark. (2000), yaptıkları çalışmada tebucanozole uygulanan her dönemde başakta tane sayısı, bin tane ağırlığı ve verimin arttığını bildirmiştir. Ayrıca araştırıcılar inokulasyon öncesi fungisit uygulamalarının inokulasyon sonrası uygulamalardan daha olumlu sonuçlar verdiğini belirtmiş ve yaptığımız çalışma ile örtüşen sonuçlar elde etmiştir. Matthies ve Buchenauer (2000), çiçeklenme yarısında (ZGS 65) inokulasyon ve tebucanozole uygulanan bitkilerde, çiçeklenme başlangıcı (ZGS 60) ve çiçeklenme tamamlandığında yapılan uygulamalardan daha olumlu yönde verimi etkilediğini bildirmiştir. Benzer şekilde diğer bir çalışmada Fusarium başak yanıklığını önlemek amacıyla yapılan tebuconazole uygulamalarının hastalığın gelişimini azaltarak başak ağırlığını arttırdığı bildirilmiştir (Jones, 2000).

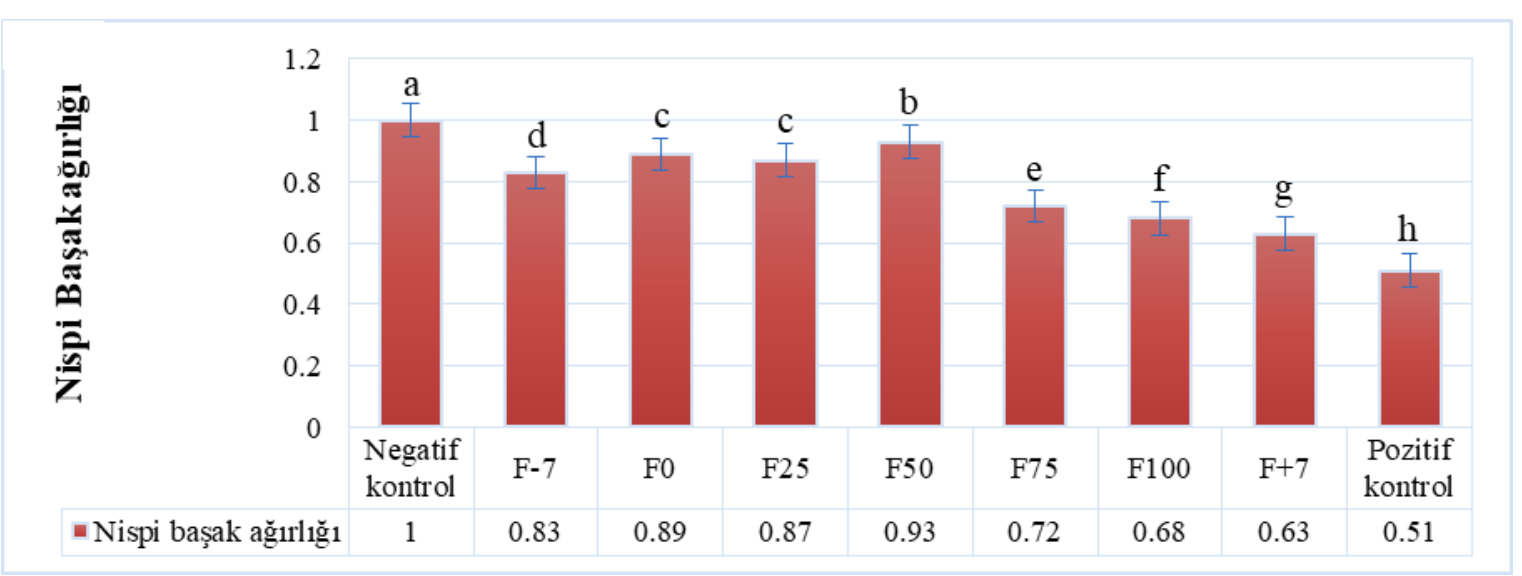

Şekil 1. Tebuconazole'un nispi başak ağırlıklarında oluşturduğu farklılıkların karşılaştırılması

*Aynı harfle gösterilen ortalamalar arasındaki fark istatiksel olarak (LSD, p=0.01) önemli değildir

\section{Sonuç}

Elde edilen sonuçlar genel olarak değerlendirildiğinde, inokulasyon öncesi, esnası ve sonrasında yapılan tebucanozole uygulamalarının hastalık gelişimini ve dolayısıyla verimi farklı seviyelerde etkilediği görülmektedir. Uygulamalar arasında en etkili zamanın $F_{50}$ (ZGS65) dönemi olduğu bunu inokulasyon öncesi ve sonrası uygulamaların takip ettiği gözlenmiştir. Bu kapsamda inokulasyon öncesi yapılan uygulamalar koruyucu etki yaratırken, inokulasyon sonrası uygulamaların hastalığın gelişimini yavaşlattığı ön görülmektedir. Ayrıca hastalık gelişimi ile başak ağırlıkları arasında ters orantı olduğu görülmüş ve enfeksiyonun en düşük olduğu $\mathrm{F}_{50}$ döneminde başak ağırlıkları en yüksek seviyeye ulaşmıştır. Bu çalışma ile fungisit uygulama zamanının önemi ortaya konmuş ve tebucanozole'un doğru zamanda uygulanması ile buğdayda başak yanıklığının ekonomik düzeyde engellenebileceği ve verimin korunabileceği tespit edilmiştir.

\section{Teşekkür}

Denemenin kurulmasındaki katkılarından dolayı Çanakkale Onsekiz Mart Üniversitesi Ziraat Fakültesi Bitki Koruma Bölümü Arş. Gör. Dr. Ali Karanfil ve istatistiksel analizlerde yardımını esirgemeyen Çanakkale Onsekiz Mart Üniversitesi Ziraat Fakültesi Tarla Bitkileri Bölümü öğretim üyesi Doç. Dr. Fatih Kahrıman’a teşekkür ederim. 
Not: Bu makale Çanakkale Onsekiz Mart Üniversitesi, Lisansüstü Eğitim Enstitüsü, Bitki Koruma Anabilim Dalında Gülsüm Palacıoğlu'nun “Farklı Çiçeklenme Döneminde Fusarium culmorum'a Karşı Yapılan İlaçlamanın Hastalık Gelişimi Ve Tane Tutumuna Etkisi”" adlı Yüksek Lisans Tez çalışmasından üretilmiştir.

\section{Kaynaklar}

Akgül, D.S., Erkilic, A., 2016. Effect of wheat cultivars, fertilizers, and fungicides on Fusarium foot rot disease of wheat. Turkish Journal of Agriculture and Forestry. 40 (1): 101-108.

BKÜ, 2021. Bitki Koruma Ürünleri Veri Tabanı. https://bku.tarim.gov.tr/ Erişim tarihi: 10 Şubat 2021.

Caldwell, C.D., MacDonald, D., Jiang, Y., Cheema, M. A., Li, J., 2017. Effect of fungicide combinations for Fusarium head blight control on disease incidence, grain yield, and quality of winter wheat, spring wheat, and barley. Canadian Journal of Plant Science. 97 (6): 1036-1045.

Cromey, M.G., Lauren, D.R., Parkes, R.A., Sinclair, K.I., Shorter, S.C., Wallace, A.R., 2001. Control of Fusarium head blight of wheat with fungicides. Australasian Plant Pathology. 30: 301-308.

Dardis, J., Walsh, E.J., 2000. Studies on the effectiveness of metconazole in controlling Fusarium head blight caused by Fusarium culmorum in spring wheat (Triticum aestivum L.). Cereal Research Communications. 4: 443-448.

Ellner, F.M., 1997. Influence of fungicide treatment on deoxynivalenol content in winter wheat artificially infected with Fusarium culmorum. Cereal Research Communications. 735-737.

Greenfield, J.E., Rossall, S., 2000. The effect of a range of novel and established fungicides on Fusarium growth and mycotoxin production. Pests and Diseases. 1 (3): 483-486.

Haeuser-Hahn, I., Dutzmann, S., Friessleben, R., Meissner, R., Goechlich, F., 2008. Prosaro (R) - A New fungicide for control of fusarium and mycotoxins in cereals. Cereal Research Communications. 26: 711-712.

Haidukowski, M., Visconti, A., Perrone, G., Vanadia, S., Pancaldi, D., Covarelli, L., Balestrazzi, R., Pascale, M., 2012. Effect of prothioconazole-based fungicides on Fusarium head blight, grain yield and deoxynivalenol accumulation in wheat under field conditions. Phytopathologia Mediterranea. 51: 236246.

Homdork, S., Fehrmann, H., Beck, R., 2000. Effects of field application of tebuconazole on yield, yield components and the mycotoxin content of Fusarium-infected wheat grain. Journal of Phytopathology. 148: $1-6$.

Jones, R.K., 2000. Assessment of Fusarium head blight of wheat and barley in response to fungicide treatment. Plant Disease. 9: 1021-1031.

Karman, M.., 1971. Bitki Koruma Araştırmalarında Genel Bilgiler Denemelerin Kuruluşu ve Değerlendirme Esasları. Tarım Bakanlı̆ğ Bölge Zirai Mücadele Araştırma Enstitüsü. 279 s. İzmir.

Köycü, N.D., Sukut, F., 2018. Buğdayda Fusarium culmorum'a ruhsatlı olmayan fungisitlerin patojen üzerine etkisi. Tekirdağ Ziraat Fakültesi Dergisi. 15 (2): 26-35.

Matny, O.N., 2015. Fusarium head blight and crown rot on wheat \& barley: losses and health risks. Adv Plants Agric Res. 2 (1): 00039.

Matthies, A., Buchenauer, H., 2000. Effect of tebuconazole (Folicur) and prochloraz (Sportak) treatments on Fusarium head scab development, yield and deoynivalenol (DON) content in grain of wheat following artifical inoculation with Fusarium culmorum. Journal of Plant Diseases and Protection. 107: 33-52.

Mauler-Machnic, A., Zahn, K., 1994. Ear Fusarioses in wheat - New findings on their epidemiyology and control with Folicur (tebuconazole). Pflanzenschutz Nachrichten Bayer. 47: 133-160.

McMullen, M., Bergstrom, G., De Wolf, E., Dill-Macky, R., Hershman, D., Shaner, G., Van Sanford, D., 2012. A unified effort to fight an enemy of wheat and barley: Fusarium head blight. Plant Disease. 96 (12): $1712-1728$.

McMullen, M., Jones, R., Gallenberg, D., 1997. Scab of wheat and Barley: a re-emerging disease of devastating impact. Plant Disease. 81: 1340-1348.

Miedaner, T., Schneider, B., Geiger, H.H., 2003. Deoxynivalenol (DON) content and Fusarium head blight resistance in segregating populations of winter rye and winter wheat. Crop Science. 43 (2): 519-526.

Milus, E.A., Parsons, C.E., 1994. Evaluation of foliar fungicides for controlling Fusarium head blight of wheat. Plant Disease. 78: 697-699.

Parry, D.W., Jenkinson, P., McLeod, L., 1995. Fusarium ear blight (scab) in small grain cereals-a review. Plant Pathology. 44: 207-238.

Pirgozliev, S.R., Ray, R.V., Edwards, S.G., Hare, M.C., Jenkinson, P., 2008. Effect of timing of fungicide application on the development of Fusarium head blight and the accumulation of deoxynivalenol (don) in winter wheat grain. Cereal Research Communications. 36: 289-299.

Shaner, G., Finney, R.E., 1977. the effect of nitrogen fertilization on the expression of slow-mildewing in knox wheat. Phytopathology. 67: 1051-1056. 
ÇOMÜ Zir. Fak. Derg. (COMU J. Agric. Fac.)

2021: 9 (1): 13-19

ISSN: 2147-8384 / e-ISSN: 2564-6826

doi: $10.33202 /$ comuagri.943142

Solel, Z., 1970. The systemic fungicidal effect of benzimidazole derivatives and thiophanate against Cercospora leaf spot of sugar beet. Phytopathology. 60 (8): 1186-1190.

Stenglein, S.A., Rogers, W.J., 2010. 7 Barley and wheat resistance genes for Fusarium head blight. Management of Fungal Plant Pathogens. 78.

Tocan, T., Mert, F., 2019. Farklı tebuconazole konsantrasyonlarının in vitro koşullarda Fusarium culmorum'un misel gelişimi ve konidi çimlenmesi üzerine olan etkisinin belirlenmesi. Çanakkale Onsekiz Mart Üniversitesi, Ziraat Fakültesi Dergisi. 7 (1): 13-20.

Verreet, J.A., Klink, H., 2001. Development of wheat integrated pest management model and their implementation into german agriculture. Türkiye IX. Fitopatoloji Kongresi Bildirileri, 3-8 Eylül, Tekirdağ.

Wiersma, J.J., Motteberg, C.D., 2005. Evaluation of five fungicide application timings for control of leaf-spot diseases and Fusarium head blight $\mathrm{n}$ hard red spring wheat. Canadian Journal of Plant Pathology. 27 (1): 25-37. 